\title{
Analysing employers' expectations of employee skills in the South African tourism industry
}

\begin{abstract}
Authors:
Faith N. Zwane ${ }^{1}$

Lindie du Plessis ${ }^{1}$

Elmarie Slabbert ${ }^{1}$

Affiliations:

${ }^{1}$ Faculty of Economic and

Business Sciences, Tourism,

Research in Economic

Environs and Society,

North-West University,

Potchefstroom Campus,

South Africa

Correspondence to:

Lindie du Plessis

Email:

lindie.duplessis@nwu.ac.za

Postal address:

Private Bag X6001,

Potchefstroom 2520,

South Africa

Dates:

Received: 24 Apr. 2013

Accepted: 22 Aug. 2013

Published: 31 Mar. 2014

How to cite this article:

Zwane, F.N., Du Plessis, L., \&

Slabbert, E. (2014). Analysing employers' expectations of employee skills in the South African tourism industry. SA Journal of Human Resource Management/SA Tydskrif vir Menslikehulpbronbestuur 12(1) Art. \#550, 9 pages. http://dx.doi.org/10.4102/ sajhrm.v12i1.550
\end{abstract}

\section{Copyright:}

(C) 2014. The Authors.

Licensee: AOSIS

OpenJournals. This work

is licensed under the

Creative Commons

Attribution License.

\section{Read online:}

Scan this $Q R$ code with your smart phone or mobile device to read online.
Orientation: Owing to the nature of the tourism industry, which is highly service orientated employees should possess certain skills such as self-reliance, people and certain specialist skills, and general employability when working in this industry. However, it seems that employees are not well enough prepared and equipped with these skills to satisfy the requirements of employers. Thus human resource practitioners need to provide more in-service training. Furthermore, there is a high turnover of employees, which adds pressure to the management of human resources.

Research purpose: This study focused on comparing employers' expectations of employee skills in the tourism industry and the skills acquired by learners in the Culture, Art, Tourism, Hospitality and Sport Skills Education Training Authorities' (CATHSSETA) programmes with regard to self-reliance, people and certain specialist skills, and general employability.

Motivation for the study: Education, training and the creation of employment are amongst the key priorities of the South African government for improving the current labour situation in the tourism industry. However, the industry has complained that learners are not prepared for the workplace. Thus, it is important to determine the skills that are supposedly lacking.

Research design, approach and method: Descriptive research, following a quantitative approach, was chosen, whereby questionnaires were distributed amongst tourism and hospitality employers listed with CATHSSETA $(N=217)$. A total of $141(n=141)$ completed questionnaires were received (a response rate of 65\%). Between 2008 and 2012, 5633 learners participated in the CATHSSETA programmes. Descriptive statistics and $t$-tests were used to analyse the data.

Main findings: Employers expect higher levels of competence than those which learners in the CATHSSETA programme can deliver. More specifically, employers indicate that learners lack skills in handling customers professionally and being proactive in solving problems. This creates difficulties in operating in the tourism business environment where service delivery is important in satisfying tourists' needs and improving loyalty levels to the establishment. Nor are employers satisfied with the ability of learners to be self-reliant. A lack of cooperation between the various role players in developing appropriate training programmes is evident.

Practical/managerial implications: It is necessary to review the current CATHSSETA programme and training providers to ensure that quality training is provided. Human resource practitioners should be involved in the development of a more appropriate programme that will adhere to the needs of the tourism industry. Training programmes should focus on the development of self-reliance and, more specifically, the ability to deal with customers in an efficient and professional manner. These are basic skills that the learners currently lack. Prospective learners should take an aptitude test to ensure that they will be able to meet the requirements of this industry and to manage the challenges facing them.

Contribution: The most important skills needed for working in the tourism environment were identified thus giving direction to the development of tourism training programmes. The importance of cooperation in developing training programmes was emphasised.

\section{Introduction}

\section{Key focus}

With the significant growth of the tourism industry in South Africa since the country's first democratic elections in 1994 (Grobler, Warnich, Carrell, Elbert \& Hatfield, 2006; Department of Tourism, 2011), various efforts have been made by the government to improve the skills levels of South Africans in this industry. The Culture, Art, Tourism, Hospitality and Sport SETA (CATHSSETA) programmes were designed to cater for this need, but the majority of tourism employers participating in the CATHSSETA programmes have indicated that they are not satisfied with the skills displayed by learners working in their tourism enterprises. Hence the question 
arises whether the CATHSSETA programme is effectively addressing the skills expectation of the tourism industry.

\section{Background}

High-season business demands in the tourism industry such as time pressure, high employee turnover, rapid money turnover - especially in small businesses - and the inability to assess the benefit of training and the expertise needed to provide training have been identified as hindering and discouraging the provision of ongoing employee training in this industry (D'Annunzio-Green, Maxwell \& Watson, 2004; Baum, Amouh \& Spivack, 1997; Jerris, 1999). Nonetheless, according to Haven-Tang and Jones (2006) as well as Lucas (2004), some of these constraints in the tourism industry are generally accepted as inevitable and natural processes.

In addition, the tourism industry is dominated by small businesses (Lucas, 2004; Baum, 1999; Peacock \& Ladkin, 2002) with some of the owner-manager positions in these small businesses being filled by expatriates, the majority of whom lack tourism knowledge and management skills and have never undergone formal tourism training ( $\mathrm{D}^{\prime}$ AnnunzioGreen et al., 2004; Haven-Tang \& Jones, 2006; Baum et al., 1997; Baum, 1995). Globally, the industry faces skills shortages in key operational, technical and managerial areas, the extent varying between developed and developing countries.

Nevertheless, tourism remains a large contributor to South Africa's gross domestic product (GDP). Furthermore, its wider economic impacts are forecast to rise by $4.8 \%$ per annum from R328.2 billion (11.4\% of GDP) in 2011 to R522.4 billion (11.5\% of GDP) by 2021. The total contribution to employment, including jobs indirectly supported by the industry, is forecast to rise by $2.5 \%$ per annum from 1334000 jobs (10.1\% of total employment) in 2011 to 1709000 (10.7\% of total employment) by 2021 (World Travel and Tourism Council (WTTC), 2011). The International Labour Organisation (ILO) (2010) states that it is said that career opportunities are more accessible in tourism than in many other sectors of the economy owing to the diverse and fragmented nature of this industry. This is evident in the support the industry provides to improve the skills and knowledge of interested learners, which has led to the development of various training institutions and programmes such as CATHSSETA learnerships and internships. Accessibility to the latter has also become a priority of the South African government and other role players across the industry, and involves both urban and rural communities (Akoojee, 2009; Pawson, 1999). Saayman (2005) argued in 2005 that the future of a successful South African tourism industry is closely linked to the development of its human resource capacity.

\section{Trends from research literature}

According to Noe, Hollenbeck, Gerhart and Wright (2009) and Chen and Klimoski (2007), the nature of the modern business environment and the challenges in the 21st century make training more important today than ever before. Various training programmes were developed to address this situation because it is important to ensure that the skills expected in the workplace and those obtained by learners during training are in accord. However, it is a continuous struggle to find adequate and skilled employees to face the challenges of the tourism industry (Saayman, 2005). Although not indicated by all business, being up to date with rapid changes, especially in the area of technology, is a skill that most students as well as new tourists do possess. This implies, however, that employees face more informed tourists with specific needs. Hence, employees are required continually to learn new skills and to be able to solve problems effectively individually and in teams to meet these needs.

The following studies identified skills necessary to function optimally in the tourism industry. Bennett, Dunne and Carre (2000) noted that employers want employees who are flexible, adaptive, proactive and transformable with an ability to learn quickly in this changing world of work. Fuller, Munro and Rainbird (2004) noted that tacit skills such as time management, organising and multitasking are often facilitated by certain forms of learning such as group work. Leadership and management positions in the industry demand skills that can only be provided through wider experience and training that focuses on cognitive and problem-solving skills, in addition to sector specific skills (Earle-Malleson, 2009). A study conducted by Groenewald and Schurink (2003) revealed that learners are able to identify their potential and talents through exposure to the core aspects of the industry that include team work, workplace environment, time management, communication skills, responsibility and a drive to work hard. Busby and Gibson (2010) further added that it is imperative for the development and inclusion of a range of transferable skills which includes teamwork, presentations and information technology (IT) skills. Diplari and Dimou (2010) found that overall experiential learning assists learners to improve their management skills and abilities, which include time management, group work skills, leadership and motivation abilities. Latagan, Dinu and Stoica (2010) caution that it must be understood that organisations do not ask for the educational systems to produce educated and skilled learners, but rather individuals with basic knowledge, commitment, innovative and entrepreneurial minds, the ability to be flexible in training and to establish and maintain social relationships.

\section{Purpose}

This study thus focused on comparing employers' expectations of employee skills in the tourism industry and the skills displayed by learners in the CATHSSETA programmes with regard to self-reliance, people and certain specialist skills, and general employability.

\section{Objectives of the research}

The objectives were to compare employers' expectations of employee skills in tourism and the skills displayed by learners in CATHSSETA programmes with regards to selfreliance, people and certain specialist skills, and general employability in the tourism industry. 


\section{Contribution to field}

This study contributes to identifying current skills gaps that hamper effective operation in the tourism industry. Quality training and development programmes can close these gaps. This will lead to improving the service levels in this industry, thus creating a more sustainable industry. The research points to the importance of cooperation between human resource practitioners and training providers in providing effective training programmes.

\section{What will follow}

In the literature review the importance of human resources in the tourism industry is analysed, as well as the current status of tourism training programmes and the skills applicable to the tourism industry. This is followed by the research design, results, discussion and implications.

\section{Literature review}

The diversity of the tourism industry requires various skills for each subsector and offers a wide range of jobs with diverse human capital requirements. It is accepted that tourism employees should be self-reliant, focused on people, have general employment skills as well as specialist skills (Fuller et al., 2004; Groenewald \& Schurink, 2003; Hjalager, 2003; Saayman \& Geldenhuys, 2003). However, after a few years of implementation it is not certain that the CATHSSETA training programmes meet the needs of the industry and whether learners are equipped with the necessary skills to function effectively in this industry. It is thus the objectives of this research to investigate the attainment of self-reliance, people and certain specialist skills, and general employability through participation in these training programmes.

\section{The importance of human resources in the tourism industry}

Macro changes such as globalisation and technological advancements have affected the hierarchical levels of organisations as well as the employment fraternity for some time now (Dulebohn \& Werling, 2007). Human resources (HR) constitutes a key management component of any business and the success of a business often depends on how well its HR is developed, managed and sustained. Businesses that promote optimal HR practices often exhibit greater market value per employee and a more cost-effective organisational performance (Walsh, Enz \& Siguaw, 2003; Giauque, Resenterra \& Siggen, 2010). HR also contributes to the quality, competitiveness and sustainability of most industries, and effects positive attributes, beneficial behaviour and other competencies in personnel (Marlow, 2006; Smith \& Smith, 2007; Mehrabad \& Brojeny, 2007 and Ivancevich, 2010).

Beech and Chadwick (2006) point out that the presence of HR acknowledges the importance of employees as an asset of any organisation. Noe et al. (2009), Valachis, Christou, Sigala and Maroudas (2009), and Swanson and Holton (2009) maintain that most businesses seek to provide a quality service and remain competitive in their industry through their employees. This primarily depends on the professionalism and relevant skills achieved through training and development. In addition, Noe et al. (2009), Smith and Smith (2007) and Swanson and Holton (2009) note that there are strong links between training and development, and business strategy. Therefore, organisations have prioritised linking training programmes to business goals which, in turn, connect with the aims of both functions in an attempt to provide employees with information, skills and an understanding of the organisation and its goals.

This is even more so in the tourism industry, which is all about people and how to handle and manage them. However, according to Zagonari (2009) and Lee-Ross and Pryce (2010), training in the tourism industry has historically not been a priority because of the high staff and cost turnover, especially in small businesses and organisations that feared that trained employees would be poached by competitors. Ladkin (2005) and D'Annunzio-Green et al. (2004) note that, in this industry, labour characteristics such as occupational diversity, relatively low pay rates, high levels of mobility, small organisations, low specificity of skills as well as the inability to assess the benefit of training and the expertise required to provide training have been identified as hindering and discouraging the provision of continuous employee training in tourism. Janes (2003) avers that the key to providing effective training lies firstly in reducing and eliminating barriers to training for organisations, and then in promoting an organisational culture that is committed to training as well as providing expertise in training design and delivery. This commitment should also be applied to the tourism industry.

\section{Tourism training programmes}

Saayman (2005) points out that, in South Africa, travel courses were introduced in the 1980s and tourism management courses were developed mainly in the early 1990s. In the relatively short period that these courses have been on offer, many challenges have been met and questions answered. According to Breytenbach (2010), these courses include tourism programmes that help to develop the skills, attributes and competencies required by different components of the industry that offer graduates a broad range of employment opportunities.

D'annunzio-Green et al. (2004) and Airey (2005) state that, in developing countries such as South Africa, vocational education that offers sector-specific skills for operational or supervisory positions in sectors such as tourism is very limited. Thus, employers are confronted with employees who are fundamentally unskilled and require considerable investment in training and development. Therefore, as indicated by Holden and Jameson (1999), this situation has called for higher education to play an increasing role in providing knowledge and skills for new entrants to the labour market through various interventions such as learnerships and internships. A learnership is primarily a workplace learning programme supported by a structured learning phase which 
results in a qualification and is facilitated by employers. It comprises study units categorised as fundamental, core, and elective unit standards. Fundamental unit standards include literacy, communications and basic mathematical skills. Core unit standards are central to the qualification (e.g. care for customers), whilst elective unit standards are selected from a range of units (e.g. manage and organise groups) (Committee for Tutorial Matters (CTM) Standing Committee, 2000; Breytenbach, 2010; CATHSSETA, 2010; Department of Education, 1998). An internship is entered into when a student has completed certain studies and takes up in-service training in an organisation which seeks to provide the appropriate work experience required for obtaining employment (CATHSSETA, 2010). These programmes are mainly facilitated by CATHSSETA in South Africa and aim at bridging the gap between the training programmes and the tourism industry.

The activities of CATHSSETA include overseeing qualification quality assurance, accrediting training providers, monitoring training provision and registering assessors. CATHSSETA therefore offers support through the two experiential activities mentioned above, namely learnerships and internships. These learning programmes are targeted at both the employed and the unemployed who wish to develop their careers in the tourism industry.

\section{Skills attributes expected by employers in the tourism industry}

According to Soanes, Hawker and Elliot (2006) skill is the ability to do something well. Business Dictionary.com (2011) and Mish (ed.) (1997) further define it as a capability and aptitude acquired through purposeful, orderly and sustained effort to smoothly and adaptively carry out complex activities or job functions involving ideas (cognitive skills), things (technical skills), and/or people (interpersonal skills). Skills review analyses developed in about the 1980s when employers persuaded government to challenge the autonomy of the training sector by reviewing and evaluating the traditional curricula because the employers felt that the curricula were not aligned to their needs (Bennet et al., 2000; Hoddinott, 2004). In addition, employees in tourism, as Diplari and Dimou (2010) explain, deem the level of skills and knowledge offered in tertiary education to be unsatisfactory and not in line with their needs. Zagonari (2009) has further added that, because of technological advancements and the mature nature of the industry's consumers, employers require specialisation and a well-educated workforce with a focus on providing a quality service. The introduction of learnerships and internships has facilitated improving the necessary skills and knowledge levels of learners.

However, the tourism industry requires specific skills. Bennett et al. (2000) and Hjalager (2003) note that employers require employees to be flexible, adaptable and transformable, and able to learn quickly. Oliver, Russel, Gilli, Hughes , Schuder, Brown and Towers (1997), and Bennett et al. (2000) state that employees need to demonstrate initiative, possess the ability to work well with others, solve problems routinely, and apply technology effectively. Bailey (1997) and Sinclair (1997) maintain that employees also need to be able to work independently with minimum supervision and to be creative. According to Bailey (1997) and Bennett et al. (2000), it is essential for employees to have acquired a broader knowledge and conceptual understanding of what their jobs entail for them to fit easily into the workplace culture. They further need to be able to acquire, organise and interpret information.

Saayman and Geldenhuys (2003) conducted a study amongst travel agents, tour operators and tour guides and identified the following as important in this field of study: computer skills, arithmetic skills, telephone skills, business writing, listening skills, language skills, negotiation skills, presentation skills, leadership and social skills, organisational skills, interpersonal skills, research skills, ethical and social responsibility skills, and cultural sensitivity skills. Some employers in tourism view communication skills as the top priority, followed by IT skills. Work experience with language skills was considered to be the least important. Employers rated generally transferable people skills above tourism knowledge when these were compared, and tourism knowledge was viewed as merely adding value. Certain companies considered experience to be more important than a degree-level qualification (Peacock \& Ladkin, 2002; EarleMalleson, 2009).

Besides the above, Holden and Jameson (1999) argue that graduates are regarded by many small and medium enterprise (SME) employers as being impractical, reluctant to get their hands dirty, slow to become productive and inclined to hold a poor view of what employment in an SME should be like. Employers express the view that the knowledge, skills, competencies and values of new graduates may not be synchronised with the needs and expectations of employers in this industry (Griesel \& Parker, 2009; Earle-Malleson, 2009; Diplari \& Dimou, 2010). Swanson and Holton (2009) add that organisations struggle to find the quality and relevance of learners' prior training useful, regarding it as either 'too generic' or 'far removed' from the workplace realities. To meet the changing requirements of companies, tertiary institutions must design programmes that venture beyond content, thereby encouraging independent learning strategies whilst focusing on the ability to think systematically and redefine problems (CTM Standing Committee, 2000).

Schuurman (2004) perceives part of the problem to be that employers are not offered an opportunity to express their real needs. He advocates that they should be engaged in all the processes, since they could provide the most relevant information on training needs for tourism labour market and ultimately also be the ones to address the major shortcomings of current training programmes in the industry. Organisations also lack experienced or suitably trained mentors with ample time on their hands. Sometimes induction is poor or even absent (National Biodiversity Institute, 2010; Groenewald \& Schurink, 2003). 
Smith and Smith (2007) also indicate that employers are becoming increasingly conscious of the value gained from their investments in training and are demanding that training be much more deliberately aligned with the strategic needs of their organisations. With regard to issues contributing to the training problems, Saayman (2005) points out that approximately $75 \%$ of the teachers have formal qualifications in the more structured sectors of tourism. Drouhin and Sweet (2000) comment that the placement of those teachers with mainly formal qualifications and little practical experience as opposed to those who are employed in the industry and have a more practical approach will remain a challenge.

It is evident from this discussion that human resources plays an important role in the functioning of the tourism industry and that certain skills are expected from the learners who are enrolled in the education and training programmes. However, many employers in tourism have voiced their concern over the quality, performance and deliverables that learners bring with them when they enter the experiential learning employment programmes in their workplaces (National Biodiversity Institute, 2010). Various studies have also indicated that the skills expected in the industry and those that are displayed by the learners do not concur - a situation which creates many challenges and impacts on the sustainability of the industry and the provision of job opportunities. With the implementation of learnerships and internships in the South African tourism industry it appeared that these challenges were being addressed. The question therefore remains: how do the skills expected by employers in the tourism industry compare with those displayed by the learners who have participated in the CATHSSETA programmes?

\section{Method}

\section{Research approach}

A descriptive research design was followed by applying a quantitative research approach where primary data were collected from employers in the tourism industry who participated in the CATHSSETA training system.

The research method used in this study will be explained under the headings that follow.

\section{Research participants}

CATHSSETA approved the survey and granted permission for the questionnaire to be distributed through their database system. Thus a census-based sampling approach was used to survey the target population $(N=217)$ by means of emails. This was done over a period of three months and yielded a sample of 141 research participants (a 65\% response rate). All employers taking part in the CATHSSETA programmes were included in the survey, which they willingly completed (see Table 1 for demographic information).

\section{Measuring instrument}

A structured questionnaire which consisted of four sections, namely (1) employer's profile (which included open and closed questions related to the sector of operation in the industry, location, years or months in business); (2) participation in the CATHSSETA programme (closed questions related to the type of programme, duration of participation); (3) identification of skills required by employers (Likert scale questions related to self-reliance, people and specialist skills, and general employability in the tourism industry), and lastly (4) identification of skills presented by learners that participated in the CATHSSETA programme (Likert scale questions related to self-reliance, people and specialist skills, and general employability in the tourism industry). The questionnaire was based on an in-depth analysis of literature and more specifically the questionnaires of Riley, Ladkin and Szivas (2002), Latagan et al. (2010), Hjalager (2003), Saayman and Geldenhuys (2003), Peacock and Ladkin (2002), Earle-Malleson (2009), Busby and Gibson (2010), and O'Neil, Allred and Baker (1997). The Cronbach alpha coefficients were examined to determine the reliability of the data and, in all cases; values were above 0.60 and therefore seen as reliable for exploratory research.

\section{Research procedure}

The employers were contacted via their CATHSSETA email account and requested to complete the questionnaire. As the CATHSSETA database was used to reach employers, authorisation was requested by the researcher and granted by the skills development and research manager. An electronic reminder was sent to the target population after one month. A web-based questionnaire system called SurveyMonkey was used as a link to the questionnaire. Where the participants did not have access to the internet, a questionnaire was faxed instead. Nowhere were participating employers referred to by name and thus their anonymity was ensured. The questionnaires were automatically stored by the SurveyMonkey electronic survey program and those that were emailed or faxed were manually captured into a Microsoft Excel spreadsheet.

TABLE 1: Profiling the employers who participated in the study.

\begin{tabular}{lllc}
\hline Variable & Category & Group & $\mathbf{\%}$ \\
\hline Business & Sector of operations in & Tourism & $12 \%$ \\
characteristics & the industry & Travel & $17 \%$ \\
& & Hospitality & $61 \%$ \\
& & Gaming and lotteries & $3 \%$ \\
& & Conservation & $7 \%$ \\
& Number of years in & $1-3$ years & $14 \%$ \\
& operation & $4-6$ years & $16 \%$ \\
& & 7-10 years & $70 \%$ \\
& Size of the business & Small (0-49 employees) & $35 \%$ \\
& (based on number of & Medium (50-149 employees) & $30 \%$ \\
ProgrammSto & employees) & Large (150+ employees) & $35 \%$ \\
characteristics & programme participation & Learnerships & $44 \%$ \\
& & Internships & $24 \%$ \\
& & Both programmes & $32 \%$ \\
& Training providers & Private training institution & $38 \%$ \\
& forming part of the & College or FET college & $39 \%$ \\
& CATHSSETA programme & University of Technology & $14 \%$ \\
& & University & $9 \%$ \\
\hline
\end{tabular}




\section{Statistical analysis}

The statistical analyses were conducted by means of SPSS (version 20.0) software program. The process consisted of two stages (SPSS, 2010). Firstly, descriptive statistics were used to analyse the socio-demographic profile of respondents and their involvement in the CATHSSETA programme. Secondly, the differences between the scores of the two groups (the skills expectations of industry and those presented by employees in the tourism workplace) were analysed by judging the difference between their means relative to the variability of their scores for which $t$-tests were performed.

\section{Results}

The results comprised a profile of the employers who had participated in the study as well as a comparison between the employers' expectations of employees' skills and the skills displayed by CATHSSETA learners in the workplace. The results were based on the opinion of the employers.

\section{Profiling the employers who participated in the study}

Table 1 indicates that most of the employers who participated in this survey operate in the hospitality industry (61\%), followed by the travel industry (17\%). Seventy per cent $(70 \%)$ of these businesses have been in operation for between seven and 10 years. These employers could therefore offer a trustworthy opinion on the skills expected from and displayed by learners. Small, medium and large businesses are all well represented in the sample. These businesses mostly participate in the learnership programme (44\%), with $32 \%$ participating in both learnerships and internships. Employers are thus equipped with information about both programmes, which can provide valuable insight. The employers recruit learners who study mostly at private training institutions (38\%) or colleges or FET colleges (39\%). The following section focuses on the comparison between the skills expected by employers and those displayed by the learners, based on the opinions of the employers mentioned above. The effectiveness of the CATHSSETA programmes is therefore assessed from the perspective of the employer.

\section{Comparison of skills expectations and the skills presented from an employer perspective}

The following discussion aims to analyse the employees' skills expected by the employers and those presented by the learners who participated in the CATHSSETA programmes from the perspective of the employers. It further aims to identify the most and the least important skills as determined by the industry to help ensure accurate coordination with the current curriculum. This was done by means of an independent sample $t$-test.

Table 2 illustrates significant statistical differences $(p<0.05)$ between the employers' skills expectations and the skills employees presented as evaluated by the employers.

The largest significant differences exist between skills expected by employers and skills presented by learners with regard to customer orientation and the employees' ability to be proactive. In the case of customer orientation, employers expect greater skill $(\mathrm{M}=4.54, \mathrm{SD}= \pm 0.77)$ from the learners than they feel the latter display $(\mathrm{M}=3.14, \mathrm{SD}= \pm 0.93)$. The same applies with regard to being proactive: employers expect a greater ability to be proactive $(\mathrm{M}=4.09, \mathrm{SD}= \pm 0.80)$ than the learners display $(\mathrm{M}=2.71, \mathrm{SD}= \pm 0.94)$. No significant difference exists between the employers' low expectations of learners' ability to speak a foreign language $(\mathrm{M}=1.69, \mathrm{SD}= \pm 0.90)$ and the learners' low level of foreign language proficiency $(\mathrm{M}=1.65, \mathrm{SD}= \pm 0.98)$.

TABLE 2: $t$-test for skills expectations and skills presented.

\begin{tabular}{|c|c|c|c|c|c|c|c|c|}
\hline \multirow[t]{2}{*}{ Skill factor } & \multirow[t]{2}{*}{ Category } & \multicolumn{2}{|c|}{ Expectations $(n=141)$} & \multicolumn{2}{|c|}{ Skills presented $(n=141)$} & \multirow{2}{*}{$\begin{array}{l}\text { Difference in } \\
\text { mean value }\end{array}$} & \multirow{2}{*}{$\begin{array}{l}\text { Standard } \\
\text { deviation }\end{array}$} & \multirow[t]{2}{*}{$p$-value } \\
\hline & & Mean value & Standard deviation & Mean value & Standard deviation & & & \\
\hline \multirow[t]{5}{*}{ Self-reliance } & Self-aware, realistic, focused and purposeful & 4.13 & \pm 0.83 & 2.93 & \pm 0.78 & 1.20 & \pm 1.11 & $0.000 *$ \\
\hline & Proactive & 4.09 & \pm 0.80 & 2.71 & \pm 0.94 & 1.38 & \pm 1.19 & $0.000 *$ \\
\hline & Willing to learn & 4.53 & \pm 0.73 & 3.43 & \pm 0.88 & 1.09 & \pm 1.07 & $0.000 *$ \\
\hline & Able to network, resourceful and an initiator & 3.39 & \pm 0.91 & 2.77 & \pm 0.88 & 0.61 & \pm 1.04 & $0.000^{*}$ \\
\hline & Good at planning, organising and prioritising & 3.66 & \pm 0.88 & 2.72 & \pm 0.92 & 0.93 & \pm 1.03 & $0.000 *$ \\
\hline \multirow[t]{6}{*}{ People skills } & The ability to work in a team & 4.38 & \pm 0.74 & 3.41 & \pm 0.83 & 0.97 & \pm 0.99 & $0.000^{*}$ \\
\hline & Effective written communication skills & 3.61 & \pm 0.86 & 3.03 & \pm 0.82 & 0.58 & \pm 1.00 & $0.000^{*}$ \\
\hline & Effective verbal communication skills & 4.08 & \pm 0.77 & 3.02 & \pm 0.88 & 1.06 & \pm 1.02 & $0.000 *$ \\
\hline & Leadership and management & 3.05 & \pm 0.89 & 2.43 & \pm 0.96 & 0.61 & \pm 0.93 & $0.000 *$ \\
\hline & Customer orientation - friendly and caring & 4.54 & \pm 0.77 & 3.14 & \pm 0.93 & 1.40 & \pm 1.09 & $0.000 *$ \\
\hline & Ability to speak a foreign language & 1.69 & \pm 0.90 & 1.65 & \pm 0.98 & 0.04 & \pm 1.03 & 0.664 \\
\hline \multirow{5}{*}{$\begin{array}{l}\text { General } \\
\text { employment skills }\end{array}$} & The ability to solve problems & 3.47 & \pm 0.96 & 2.88 & \pm 0.89 & 0.59 & \pm 1.22 & $0.000 *$ \\
\hline & Flexibility & 3.77 & \pm 0.99 & 2.96 & \pm 0.84 & 0.81 & \pm 1.29 & $0.000^{*}$ \\
\hline & Numeracy & 3.38 & \pm 1.02 & 2.93 & \pm 0.79 & 0.44 & \pm 1.40 & $0.000 *$ \\
\hline & Commitment & 4.25 & \pm 1.16 & 3.21 & \pm 0.88 & 1.04 & \pm 1.60 & $0.000 *$ \\
\hline & Professionalism & 4.28 & \pm 1.16 & 3.09 & \pm 0.90 & 1.18 & \pm 1.63 & $0.000 *$ \\
\hline \multirow[t]{2}{*}{ Specialist skills } & Technical and computer skills & 3.46 & \pm 0.95 & 2.78 & \pm 0.91 & 0.68 & \pm 1.07 & $0.000^{*}$ \\
\hline & Tourism knowledge & 3.15 & \pm 1.09 & 2.60 & \pm 0.98 & 0.56 & \pm 1.00 & $0.000 *$ \\
\hline
\end{tabular}


The least significant difference occurs for numeracy. However, employers still expect better proficiency $(\mathrm{M}=3.38, \mathrm{SD}= \pm 1.02)$ than is displayed by the learners $(\mathrm{M}=2.93, \mathrm{SD}= \pm 0.79)$. The employers' highest expectations relate to the ability of learners to work with customers $(M=4.54)$, the willingness of learners to learn $(\mathrm{M}=4.53)$, and the ability of learners to work in a team $(M=4.38)$ and to be professional $(M=4.28)$.

\section{Comparison of skills categories}

The skills as identified in the literature were categorised as follows: self-reliance, people skills, general employment skills and specialist skills.

In the analysis of the skills categories, significant differences exist in all four groups (see Table 3). In all cases, the skills expectations of employers are much higher than the skills presented by the learners. For instance, it is evident that employers expect higher levels of self-reliance $(\mathrm{M}=3.96$, $\mathrm{SD}= \pm 0.62)$ than the learners display $(\mathrm{M}=2.91, \mathrm{SD}= \pm 0.75)$. Significant differences occur with regard to the learners' ability to network, be resourceful and act as initiators in the category of self-reliance.

\section{Discussion}

\section{Outline of the results}

The aim of this study was to compare the employers' expectations of employees' skills in the tourism industry with the skills presented by learners in the CATHSSETA programmes with regard to self-reliance, people and specialist skills, and general employability.

The results show that hospitality sector employers are the majority implementers of these programmes. The participating businesses have been in operation for between seven and ten years, therefore are able to give a trustworthy opinion on the skills expected from and presented by learners.

\section{Most significant findings evident from the results}

Firstly, it was found that significant differences exist for all the skills assessed but one. In all instances, the employers expected the learners to be better skilled as a result of their participation in the training programmes. Therefore the content and outcomes of the CATHSSETA programmes should be revisited. These findings can be attributed either to employer expectations being too high or the training programmes being inadequate to satisfy the human resource needs of employers.

TABLE 3: $t$-test for skills expectation factors and skills presented.

\begin{tabular}{|c|c|c|c|c|c|}
\hline \multirow[t]{2}{*}{ Skill factors } & \multicolumn{2}{|c|}{ Expectations $(n=141)$} & \multicolumn{2}{|c|}{ Skills presented $(n=141)$} & \multirow[t]{2}{*}{$p$-value } \\
\hline & Mean value & $\begin{array}{l}\text { Standard } \\
\text { deviation }\end{array}$ & Mean value & $\begin{array}{l}\text { Standard } \\
\text { deviation }\end{array}$ & \\
\hline Self-reliance & 3.96 & \pm 0.62 & 2.91 & \pm 0.75 & $0.026^{*}$ \\
\hline People skills & 3.56 & \pm 0.55 & 2.78 & \pm 0.70 & $0.000 *$ \\
\hline $\begin{array}{l}\text { General } \\
\text { employment skills }\end{array}$ & 3.66 & \pm 0.82 & 2.90 & \pm 0.69 & $0.031^{*}$ \\
\hline Specialist skills & 3.30 & \pm 0.86 & 2.68 & \pm 0.85 & $0.000 *$ \\
\hline
\end{tabular}

$*, p \leq 0.05$
Secondly, the largest significant differences were found between the skills expected by employers and those displayed by learners with reference to customer orientation and the ability of learners to be proactive. Regarding customer orientation, employers expected learners to be better oriented towards their customers than the learners currently appear to display. According to them, learners are not adequately prepared to work with customers and satisfy their needs. Thorough attention must be paid to improving customer orientation skills as learners were unable to meet the high demands set by the employers. Tajeddini (2010) indicated that the tourism industry demands a more customer-oriented approach where value to the customer is provided efficiently and continuously (Choi \& Chu, 2001). With reference to being proactive, it was found that employers expected higher levels of proactiveness than learners presented. This is supported by Bennett et al. (2000) and Hjalager (2003), who indicate that employers in the tourism industry demand flexible, proactive and adaptive employees. Thus it appears that employers believe that the current CATHSSETA training programmes do not adequately equip learners with customer orientation skills or improve their ability to be proactive.

Thirdly, the ability to speak a foreign language was not considered important. This was also found in studies conducted by Peacock and Ladkin (2002), and Earle-Malleson (2009). Most South Africans speak English and can therefore accommodate foreign and local visitors without being able to speak a foreign language.

Fourthly, the least significant difference was found relating to numeracy. Employers' expectations and the skills presented by the learners were almost on the same level. However Amoah and Baum (1997) found a gap between what is offered by education institutions and what the industry seeks in the United Kingdom. Littlejohn and Watson (2004) also identified the importance of numeracy as part of a tourism curriculum. The CATHSSETA programme should therefore continue to improve the numeracy skills of participating learners.

Finally, it is evident from the findings of the skills categories that the most significant difference was found to relate to self-reliance. Employers were not satisfied with the learners' level of being proactive, their willingness to learn, and their ability to network, plan and organise effectively. Oliver et al. (1997) indicate that these factors are very important as they form a bridge between the individual, society and the environment. Eraqi (2006) found that the development of employees' empowerment and autonomy are important in providing quality tourism services. More attention should therefore be given to these skills in the training programme.

\section{Practical implications and recommendations}

The following implications can be derived from the above discussions

Firstly, the comparison between the skills expected by employers and those presented by CATHSSETA learners reveal various significant differences. This is of concern for 
human resource practitioners in the South African tourism industry, especially considering the money spent on these programmes and the number of learners involved. The employers expect much more skill from the learners than they currently display. It is evident that tourism human resource practitioners and CATHSSETA need to improve their cooperative efforts and collaborate to adapt the current training programmes so that they equip the learners with the required skills and knowledge. A more coordinated effort is needed to improve the current outcomes of these programmes. The result of such action could be that human resource practitioners would provide less in-house training to learners upon their arrival in the tourism enterprise.

Secondly, training programmes for the tourism industry should emphasise the skills and knowledge pertaining to the handling of and orientation towards customers. This is the lifeblood of any tourism business and if learners fail in this important task it might impact on the success and sustainability of the business. It is recommended that human resource practitioners also expose learners to role plays and videos showcasing ways to handle customers. Although a lack of proper customer orientation has been found in various previous studies, it remains a challenge that needs to be addressed.

Thirdly, the gap regarding self-reliance, considered to be an important element for entering the industry, requires attention. CATHSSETA should ensure that learners are adequately prepared to deal with networking opportunities, planning, organising and prioritising certain tasks, and that they show a willingness to learn. Employers should make sure there is a good fit between a person and the job. This will lead to better outcomes, since some self-reliance skills are personality traits.

\section{Limitations and suggestions for future research}

A possible limitation of this study is the number of participants, which, although representative of the employers involved in the CATHSSETA programme, is not necessarily representative of the tourism industry. However, the bigger role players are participating in this programme and thus provide a good view of the current situation. It is suggested that the research is also conducted in other sectors of the tourism industry to determine the specific skills needed by certain sectors.

\section{Conclusion}

This study compared the employers' expectations of employees' skills in tourism and the skills displayed by CATHSSETA learners. The importance of certain skills have been highlighted in the literature, but this study revealed that various gaps still exist between the skills that employers demand and those that learners are able to deliver after having completed their training programmes. The expectations of the employers exceed the level of skill that learners are currently able to deliver; this causes frustration and, very importantly, also influences the growth of the tourism industry. Human resource practitioners in the South African tourism industry need to evaluate the current workplace environment to determine how training programmes can be adapted to the needs of industry, and also to evaluate the role of the industry in this process. This will directly impact the sustainability of the tourism industry and assist in improving the quality of tourism services in this country. This research indicated that, although government institutions such as CATHSSETA aim at providing an opportunity for young South Africans to obtain training and education in the tourism industry, learners are not yet competent in the workplace. The skills gaps identified in this study should be addressed.

\section{Acknowledgement}

Financial assistance from the Culture, Arts, Tourism, Hospitality and Sport Sector Education and Training Authority (CATHSSETA) is gratefully acknowledged. Statements and suggestions made in this study are those of the author and should not be regarded as those of above institution.

\section{Competing interest}

The authors declare that they have no financial or personal relationships which may have inappropriately influenced them in writing this article.

\section{Authors' contributions}

F.N.Z. (North-West University) conducted the research for her Master's degree and therefore wrote the concept paper. L.d.P. (North-West University) was the supervisor of this study and E.S. (North-West University) was co-supervisor. Both these supervisors assisted in writing the final manuscript.

\section{References}

Airey, D.W. (2005). Growth and development. In D.W. Airey \& J. Tribe (Eds.), An international handbook of tourism education, (pp. 13-22). Oxford: Elsevier. http:// dx.doi.org/10.1016/B978-0-08-044667-7.50005-7

Akoojee, S. (2009). Scarce skills and public technical and vocational education and training in South Africa: Twin challenge or two sides of the same coin? Southern African Review of Education, 15(2), 117-138.

Amoah, V.A., \& Baum, T. (1997). Tourism education: Policy versus practice. Internationa Journal of Contemporary Hospitality Management, 9(1), 5-12. http://dx.doi. org/10.1108/09596119710157531

Bailey, T. (1997). Changing in the nature of work: Implications for skills and assessment. In H.F O'Neil (Ed.), Workforce readiness: Competencies and assessment, (pp. 27-45). New Jersey: Lawrence Erlbaum Associates.

Baum, T. (1995). Managing human resources in the European hospitality industry: A strategic approach. London: Chapman and Hall.

Baum, T. (1999). Human resource management in tourism small business sector: Policy dimension. In D. Lee-Ross (Ed), HRM in tourism and hospitality: International perspectives on small to medium sized enterprises, (pp. 3-16). New York: Cassell.

Baum, T., Amouh, V., \& Spivack, S. (1997). Policy dimensions of human resources management in the tourism and hospitality industries. International Journal of Contemporary Hospitality Management, 9(5/6), 221-229. http://dx.doi.org/10.1108/ 09596119710172615

Beech, J., \& Chadwick, S. (2006). Introduction - The unique evolution of tourism as 'business'. In J. George \& S. Chadwick (Ed.), The business of tourism management, (pp. 3-18). Essex: Pearson Education Limited.

Bennett, N., Dunne, E., \& Carre, C. (2000). Skills development in higher education and employment. Buckingham: SHRE and Open University Press.

Breytenbach, A. (2010). An evaluation of tourism industry perceptions of tourism programmes of selected further and higher education institutions in the Western Cape. Thesis and dissertations, CPUT. Paper 149. Retrieved August 30, 2011, from http://dk.cput.ac.za/td_cput/149

Busby, G., \& Gibson, P. (2010). Tourism and hospitality internship experience overseas: A British perspective. Journal of Hospitality, Leisure, Sport and Tourism Education, 9(1) , 4-12. http://dx.doi.org/10.3794/johlste.91.244 
Business dictionary. (2011). Definition of skill. Retrieved Aug 19, 2011, from http:// www.businessdictionary.com/definition/skill.html

Culture, Art, Tourism, Hospitality and Sport Skills Education Training Authorities (CATHSSETA). (2010). Learnership policy. Sandton: CATHSSETA.

Chen, G., \& Klimoski, R.J. (2007). Training and development of human resources at work: Is the state of our science string? Journal of Human Resource Management Review, 17(2), 180-190. http://dx.doi.org/10.1016/j.hrmr.2007.03.004

Choi, T.Y., \& Chu, R. (2001). Determinants of hotel guests' satisfaction and repeat patronage in the Hong Kong hotel industry. International Journal of Hospitality Management 29(3), 277-297. http://dx.doi.org/10.1016/S0278-4319(01)00006-8

Committee for Tutorial Matters (СTM) Standing Committee: Co-operative Education (2000). Best practice in co-operative education. Durban: South African Society for (2000). Best practice in co-opera
Co-operative Education (SASCE).

D’Annunzio-Green, N., Maxwell, G.A., \& Watson, S. (2004). Human resource management: International perspective in hospitality and tourism. Surrey: Thomson Learning.

Department of Tourism (2011). National Tourism Sector Strategy. Pretoria: Government Printer.

Diplari, A., \& Dimou, I. (2010). Public tourism education and training in Greece. Journa of Industry and Higher Education, 24(2), 115-120. http://dx.doi.org/10.5367/ 000000010791190976

Drouhin, M., \& Sweet, R. (2000). From initial education to working life: Making transition work.. In D. Atchoarena (Ed.), New trends in technical and vocational education, (pp. 1-175). Paris: UNESCO.

Dulebohn, J.H., \& Werling, S.E. (2007). Compensation research past, present and future. Journal of Human Resource Management Review, 17(2), 191-207. http:// dx.doi.org/10.1016/j.hrmr.2007.03.002

Earle-Malleson, N. (2009). Tourism. In A. Kraak (Ed.), Sectors and skills: The need for policy alignment, (pp. 300-317). Cape Town: HSRC Press.

Eraqi, M.I. (2006). Tourism services quality in Egypt. Benchmarking: An Internationa Journal, 13(4), 469-492. http://dx.doi.org/10.1108/14635770610676308

Fuller, A., Munro, A., \& Rainbird, H. (2004). Introduction and overview. In H. Rainbird, A. Fuller \& A. Munro (Eds.), Workplace learning in context, (pp. 1-18). London: Routledge.

Giauque, D., Resenterra, F., \& Siggen, M. (2010). The relationship between HRM practices and organisational commitment of knowledge workers: Facts obtained from Swiss SMEs. Journal of Human Resource Development International, 13(2), 185-205. SMEs. Journal of Human Resource Development
http://dx.doi.org/10.1080/13678861003703716

Griesel, H., \& Parker, B. (2009). A baseline study on South African graduates from the perspective of employers. (A baseline study undertaken by Higher Education South Africa and the South African Qualification Authority). Pretoria: HESA.

Grobler, P., Warnich, S., Carrell, R.M., Elbert, F.N., \& Hatfield, R.D. (2006). Human resource management in South Africa (3rd edn.). London: Thomson Learning.

Groenewald, T., \& Schurink, W. (2003). The contribution of co-operative education in the growing of talent in South Africa: A qualitative phenomenological exploration. South African Journal of Human Resource Management, 1(3), 93-104.

Haven-Tang, C., \& Jones, E. (2006). Human resource management in tourism businesses. In J. Beech \& S. Chadwick (Eds.). The business of tourism management, (pp. 89-113). Essex: Pearson Education Limited.

Hjalager, A.M. (2003). Global tourism careers: Opportunities and dilemmas facing higher education in tourism. Journal of Hospitality, Leisure, Sports and Tourism higher education in tourism. Journal of Hospitality, Leisure, Sp
Education, 2(2), 26-38. http://dx.doi.org/10.3794/johlste.22.35

Hoddinott, S. (2004). The assessment of workers basic skills: A critique based on evidence from the United States, Canada and England. In H. Rainbird, A. Fuller \& A. Munro (Eds.), Workplace learning in context, (pp. 89-106). London: Routledge.

Holden, R., \& Jameson, S. (1999). Employing graduates in hospitality small to mediumsized enterprises: Context and issues. In D. Lee-Ross (Ed.), HRM in tourism and hospitality: International perspectives on small to medium-sized enterprise, (pp. 48-66). London: Cassell.

International Labour Organisation (2010). Developments and challenges in the hospitality and tourism sector: Issues paper for discussion at the Global Dialogue Forum for the Hotels, Catering and Tourism Sector. Geneva: International Labour Office.

Ivancevich, J.M. (2010). Human resource management (11th edn.). New York: McGrawHill.

Janes, L.P. (2003). Training and development in tourism organizations. In S. Kusluvan (Ed.), Managing employee attitudes and behaviours in the tourism and hospitality industry, (pp. 310-338). New York: Nova Science Publishers.

Jerris, L. (1999). Human resources management for hospitality. New Jersey: PrenticeHall.

Ladkin, A. (2005). Careers and employment. In D. Airey \& J. Tribe (Eds.), An internationa handbook of tourism education, (pp 437-450). Oxford: Elsevier. http://dx.doi. org/10.1016/B978-0-08-044667-7.50034-3

Latagan, M., Dinu, C., \& Stoica, A.M. (2010). Continuous training of human resources - A solution to crisis going out. Procedia - Social and Behavioural Sciences, 2(2), 5139-5146. http://dx.doi.org/10.1016/j.sbspro.2010.03.835
Lee-Ross, D., \& Pryce, J. (2010). Human resources and tourism: Skills, culture and industry. London: Channel View.

Littlejohn, D., \& Watson, S. (2004). Developing graduate managers for hospitality and tourism. International Journal of Contemporary Hospitality Management, 16(7), 408-414. http://dx.doi.org/10.1108/09596110410559096

Lucas, R. (2004). Employment relations in the hospitality and tourism industries. London Routledge. http://dx.doi.org/10.4324/9780203644553

Marlow, S. (2006). Human resource management in smaller firms: A contradiction in terms. Journal of Human Resource Management Review, 16(4), 467-477. http:// dx.doi.org/10.1016/j.hrmr.2006.08.004

Mehrabad, M.S., \& Brojeny, M.F. (2007). The development of an expert system for effective selection and appointment of the jobs applicants in human resource management. Journal of Computer and Industrial Engineering, 53(2), 306-312. http://dx.doi.org/10.1016/j.cie.2007.06.023

Mish, C.F. (Ed.). (1997). The Merriam Webster dictionary. Springfield, MA: Merriam Webster Incorporated.

National Biodiversity Institute (2010). Survey to identify the best support for internships in the biodiversity sector: Report and recommendations. Cape Town: SANBI.

Noe, R.A., Hollenbeck, J.H., Gerhart, B., \& Wright, P.M. (2009). Fundamentals of human resource management (3rd edn.). New York: McGraw-Hill.

O'Neil, H.F., Allred, K., \& Baker, E.L. (1997). Review of workforce readiness theoretical framework. In H. F. O'Neil (Ed.), Workforce readiness: Competencies and assessment (pp. 3-25). Mahwah, NJ: Lawrence Erlbaum Associates.

Oliver, K.M., Russel, C., Gilli, L.M., Hughes, R.A., Schuder, T., Brown, J.L., \& Towers, W. (1997). Skills for success in Maryland: Beyond workplace readiness. In H.F. O'Neil (Ed.), Workforce readiness: Competencies and assessment, (pp. 47-76). New Jersey: Lawrence Erlbaum Associates. http://dx.doi.org/10.2466/pms.1997.85.1.123

Pawson, P. (1999). Cooperative education in the South African tourism industry: Strategy implementation at Technikon Pretoria. Conference proceedings of the World Conference on Cooperative Education of the World Association for Cooperative Education, 4-7 July 1999. USA: Washington, DC.

Peacock, N., \& Ladkin, A. (2002). Exploring relationships between higher education and industry, a case study of a university and the local tourism industry. Industry and
HigherEducation,16(6),393-401. http://dx.doi.org/10.5367/000000002101296568

Riley, M., Ladkin, A., \& Szivas, E. (2002). Tourism employment: Analysis and planning. Clevedon: Channel View Publications.

Saayman, M. (2005). South Africa. In D. Airey \& J. Tribe (Ed.), An international handbook of tourism education (pp. 257-269). London: Elsevier. http://dx.doi.org/10.1016/ B978-0-08-044667-7.50021-5

Saayman, M., \& Geldenhuys, S. (2003). An analysis of skills required for selected sectors of the tourism industry. South African Journal in Sports, Physical Education and Recreation, 25(1), 83-95.

Schuurman, L. (2004). An evaluation of tourism training: A conceptual analysis. Master's dissertation. Cape Town: Cape Technikon.

Sinclair, K.E. (1997). Workforce competencies of college graduates. In H.F. O'Neil (Ed.), Workforce readiness: Competencies and assessment, (pp. 103-120). New Jersey: Lawrence Erlbaum Associates.

Smith, A., \& Smith, E. (2007). The role of training in the development of human resource management in Australian organisations. Journal of Human Resource Development management in Australian organisations. Journal of Human Resource Development
International, 10(3), 263-279. http://dx.doi.org/10.1080/13678860701515208

Soanes, C., Hawker, S., \& Elliot, J. (Eds.). (2006). Paperback Oxford English dictionary. New York: Oxford University Press.

South Africa. Department of Education. (1998). Skills Development Act No 97, 1998 Pretoria: Government Printer.

SPSS Inc. (2010). SPSS 16.0 for Windows, Release 16.0.0. Copyright ${ }^{\circ}$ by SPSS Inc., Chicago, Illinois.

Swanson, R.A., \& Holton III, E.F. (2009). Foundations of human resource development (2nd edn.). San Francisco: Berrett-Koehler. http://dx.doi.org/10.1002/hrdq.20002

Tajeddini, K. (2010). Effect of customer orientation and entrepreneurial orientation on innovativeness: Evidence from the hotel industry in Switzerland. Tourism Management, 31, 221-231. http://dx.doi.org/10.1016/j.tourman.2009.02.013

Valachis, I., Christou, E., Sigala, M., \& Maroudas, L. (2009). Developing human resources' skills and knowledge in tourism and hospitality industry through the determination of quality of training programs. Journal of Tourism and Hospitality Management, 15(1), 61-72.

Walsh, K., Enz, C.A., \& Siguaw, J.A. (2003). Innovations in hospitality human resource cases from the U.S. lodging industry. In S. Kusluvan (Ed.), Managing employee attitudes and behaviours in the tourism and hospitality industry, (pp. 788-803). New York: Nova Science Publishers.

World Travel, \& Tourism Council (2011). Travel and tourism economic impact. London: WTTC.

Zagonari, F. (2009). Balancing tourism education and training. International Journal of Hospitality Management, 28(1), 2-9. http://dx.doi.org/10.1016/j.ijhm.2008.03.006 